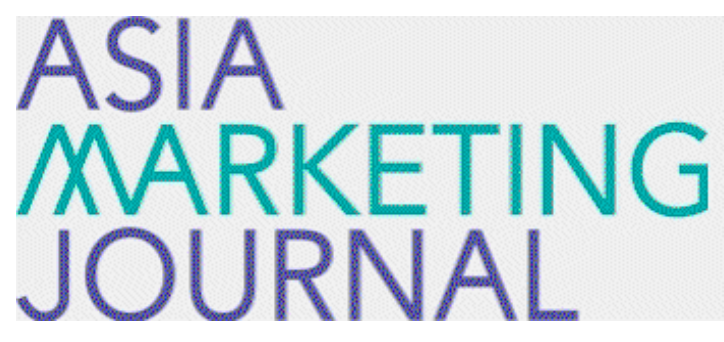

ASIA MARKETING JOURNAL

Volume 16 | Issue 1

Article 11

4-30-2014

\title{
SK Energy"s Customer Satisfaction
}

Min Sun Yeu

Doo Hee Lee

Jae Hwan Kim

Follow this and additional works at: https://amj.kma.re.kr/journal

Part of the Marketing Commons

\section{Recommended Citation}

Yeu, Min Sun; Lee, Doo Hee; and Kim, Jae Hwan (2014) "SK Energy"s Customer Satisfaction," Asia Marketing Journal: Vol. 16 : Iss. 1 , Article 11.

Available at: https://doi.org/10.53728/2765-6500.1534

This Article is brought to you for free and open access by Asia Marketing Journal. It has been accepted for inclusion in Asia Marketing Journal by an authorized editor of Asia Marketing Journal. 


\title{
SK Energy's Customer Satisfaction
}

\author{
Minsun $\mathrm{Yeu}^{*}$ \\ Doo-Hee Lee** \\ Jaehwan Kim***
}

Many oil refinery companies have been proactively carried out marketing activities to survive in highly intensified service station industry. In 2012, SK Energy ranked number one in three customer satisfaction surveys (NCSI, KCSI, and KS-SQI).

SK Energy's success is in its differentiated customer satisfaction business strategy. SK Energy has been implementing various marketing activities. As a part of the activities, it issued an affinity credit card with on spot discount privilege for the first time in the oil refinery industry. SK Energy also issued EnClean bonus card for OK Cashbag points that can be used for discounts at the service stations. On top of all, SK Energy generated point value-up with '3K Exclusive Privilege' program. In addition, team 'CS 119' was formed to noticeably improve the service. 'CS 119' visited each service station, diagnosed its CS service level then provided customized field training for improvement. Long-term implementation of 'ACE Program', a field-base CS monitoring system, regularly checked customer satisfaction level. 'ACE Program' has significantly contributed improving SK Service Station's service quality and customer satisfaction. This case reviews customer satisfaction marketing activities SK Energy carried out. The focus is on distinctive factors that distinguish SK Energy's customer satisfaction marketing activities from competitors.

Key words: SK Energy, Customer Satisfaction

\section{Introduction}

No matter how big or small the organization is, achieving customer satisfaction is the most important task encountered by any company.
In fact, Fornell (1992) stated that the higher the customer satisfaction, the higher the business performance will be. Increased customer satisfaction leads to higher customer loyalty and lower price sensitivity allowing business to retain existing customers even especially when

\footnotetext{
* Ph.D. candidate in Marketing Korea University Business School

** Professor of Marketing Korea University Business School

*** Professor of Marketing Korea University Business School(jbayes@korea.ac.kr), Corresponding Author
} 
competition intensifies. Furthermore, higher customer satisfaction will reduce future transaction cost, uncertainty cost as well as new customer acquisition cost. Most businesses invest at its best to provide active and unique customer satisfaction strategy. Service station is not an exception. In the past, service station had limited function solely providing 'fuel-fulfilling' service. Thus, price was one of the only important variables in terms of choosing the service station. Back then service stations typically gave away uniformed promotional gifts such as a bottle of distilled water or a pack of facial tissue. It was hardly possible for customers to clearly distinguish between the oil quality and prices among the refineries. Besides, competition became serious after the zoning restrictions limiting the number of service station within certain distances were lifted. The elimination of such restriction led to exponential growth in number of service stations from 3,315 in 1990 to 13,003 in the end of 2010 (Korea Oil Station Association). Recently, the competition within the industry even intensified with the advent of 'Economical Service Station' subsidized by Petroleum Public Corporation (Noh, 2012). Accordingly, it became difficult to satisfy customers even with free car wash coupons, point mileage program and price discount in addition to the existing promotional gifts and giveaways. Discovering customer's real needs and turning them into customer values are left for the path to customer satisfaction.
SK Energy's management philosophy is to concentrate all its internal resources on customer happiness. SK Energy has been putting efforts in different dimensions by prioritizing its customer happiness management philosophy to maximize customer satisfaction and to practice customer-centered management. As a result, SK Energy continuously displayed superior market leadership based on its differentiated brand value. This paper aims to learn about SK Energy's customer satisfaction marketing activities. Followed by brief introduction of SK Energy, the paper will illustrate the characteristics of service station industry. Then the paper will thoroughly analyze SK Energy's customer satisfaction marketing activities from new customer acquisition to loyal customers retention that eventually led to higher customer satisfaction. Finally, the paper will state future implications and challenges for SK Energy's customer satisfaction performance.

\section{Introduction to SK Energy}

\subsection{History of SK Energy}

SK Energy was established in 1962 under the name of Korea Petroleum Company (SK Corporation) as the first oil refinery company in South Korea and soon became the leading company in energy industry. The company 
〈Table 1〉SK Energy History

\begin{tabular}{|c|l|}
\hline Year $1962 \sim 1969$ & First refinery company in South Korea \\
\hline Year 1970 $\sim 1979$ & Play pivotal role in national economic development \\
\hline Year 1980 $\sim 1989$ & Construct foundation as general energy, general chemical company \\
\hline Year 1990 $\sim 1999$ & Make a forward move as $21^{\text {st }}$ century global energy/chemical company \\
\hline Year 2000 $\sim 2009$ & APAC's leading energy-chemical company \\
\hline Year 2010 $\sim$ Present & Technology-base global general energy company \\
\hline
\end{tabular}

showed persistent growth and played pivotal role in economic development of the country for past five decades.

In 1960s, when South Korea strived for economic independence and modernization, SK Energy operated the first oil refinery plant in 1964 and provided the first domestic petroleum products. For more than 40 years after its operation of the first plant, SK Energy critically contributed to national economic development with steady supply of petroleum energy. In 1970s, when economic development accelerated, SK Energy continued to maintain steady supply of petroleum energy by expanding its plants. Meanwhile, SK Energy went into petrochemical industry, which was selected as the core business of the second five-year economic development plan of South Korea. It was the first in record to operate aromatic and ethylene production facility and supply chemical material in Korea. This opened up a new chapter in petrochemical industry, the heart of modern industry.

Transformed under Sunkyung Group, in 1980, SK Energy started to build solid foundations to become a leading global energy and chemical company. Along with oil refinery business, SK Energy successfully entered petroleum development business, gas and coal business. SK Energy also strengthened its positioning as a general petrochemical company by accessing downstream sector of petrochemical industry taking advantage of the business in base oil (lubricant) and synthetic resins.

By 1990s, SK Energy introduced membership program, 'EnClean Bonus Card,' for the first time in the industry. Based on the 8.2 million customer database and 3,700 service station network built up by the membership program, SK Energy's market share remained number one. The company placed strong base as general chemical company comprehensively covering all the phases from oil development, oil refinery, sales and introduction of lubricating oil, ZIC. In chemical sector, SK Energy not only entered base oil industry but also entered fine chemical and biochemical industry to position itself as general chemical company. While focusing on its core businesses, energy and chemical industry, in 2000s, SK Energy reinforced 
its competitive advantage in global market. At the same time, the company also concentrated its resources constructing basis for future development and exceeded 11billion U.S. dollar export in petroleum/chemical/lubricating oil products recording the highest amount in nationwide oil refinery industry in 2008.

In July 2007, SK Energy transformed into holding company to increase shareholders' value and to foster transparency in its governance structure. With today's technology, SK Energy now puts emphasis on global business management strategy and future energy development. It aims to become a leading global general energy company.

\subsection{SK Energy's Oil Refinery Business}

SK Energy's refinery business is divided into petroleum, gas and special products units. Petroleum business, in particular, managed to outperform even during the global economic recession triggered from finance crisis in 2009. The effort put on each value chain enabled SK Energy to make notable achievements in overseas market development during this period and successfully maintained its position as number one in the industry.

In 2010, as a response to declining refinery profit market condition, SK Energy transformed its profit structure by reorganizing management process. Since 2011, SK Energy consistently checked and improved optimization process of the entire value chain preparing itself to the potential change in price of crude oil and petroleum based products. The company reinforced its ability to response to such abrupt changes with optimized operation of existing infrastructure.

Based on these efforts, SK Energy with customer management business strategy also has been pioneer in marketing activities retaining its position as number one in the industry. The first evidence is the effort on the quality guarantee program in order to gain customer trust blocking possible supply of counterfeit petroleum products. Next is provision of differentiated CRM activities and customer care service with EnClean Bonus card. SK Energy affinity credit card is the last example. The affinity credit card allows customers to enjoy many privileges such as on spot discount for filling up and point mileage program.

As a result, SK Energy was able to take proactive initiatives in fast-changing and competitive business environment. The company was able to remain number one (36.6\%) with the largest market share among all petroleumselling service stations. (E-Today, 2013) (see $\langle$ Figure 1〉)

\section{South Korea's Current Service Station Industry}

The increased oil price pulled up the number 


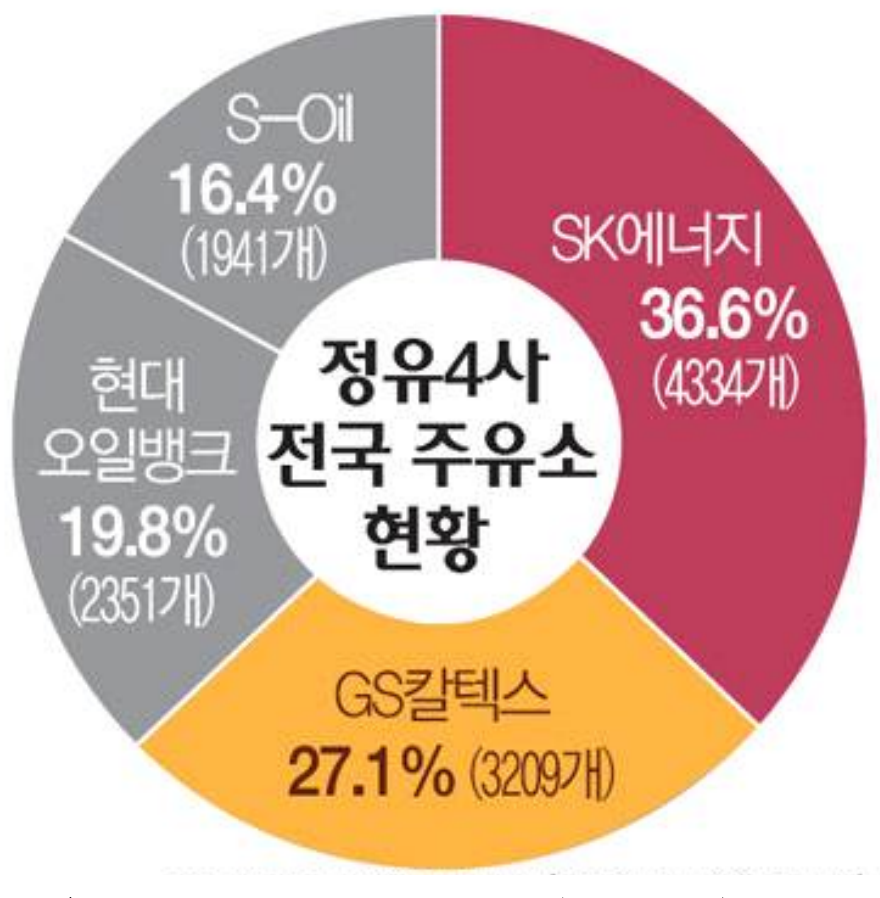

* Source: Korea Oil Station Association (October 2012)

of service stations. The growth started in October 2010 and reached the peak in December 2010 with total of 13,003 service stations nationwide. This was also the consequence from the abolition of zoning restrictions.' In 1997, the obligation to notify the petroleum price was eliminated leaving the price autonomy to oil refineries in private sector. The fierce competition soon began with three times more market participants and free price competition. The industry became even more competitive after mid-2000s as agricultural cooperative and hy- permarkets opened up service stations with low price. Furthermore, 'Economical Service Station', subsidized by Petroleum Public Corporation, supplied petroleum at an economical price. Customers would look for cheaper service stations and their preferences for lower price intensified the price competition.

Though the number of service stations reached its peak in 2010, the number declined throughout next few years recording 12,901 in late 2011, and 12,830 in September 2012 (Noh, 2012). In other words, the number of service stations closed

1) November 15, 1995, zoning restrictions in city area limiting number of service stations within given distance (district/ city: 500m, town: $1 \mathrm{~km}$ ) were eliminated. Accordingly, all zoning restrictions on service stations were lifted up (Korea Petroleum Association, 1995). 
down increased from 101 in 2008, 109 in 2009, 127 in 2010, 205 in 2011, to 210 in September 2012 (Korea Oil Station Association, 2012). The excessive competition eventually led incessant close down of service stations and decreased sales margin. Those stations with insufficient sales margin suffered from loss and ended up exiting the business.

The sales margin was almost $10 \%$ a decade ago but it dropped significantly to $2 \sim 3 \%$ in 2012 (Kim, 2012).

Petroleum-based products are price inelastic giving suppliers higher bargaining power. On the other hand, petroleum itself generally cannot be differentiated by its quality. It is also categorized as a commodity product that customers encounter everyday. Tightened competition among service stations resulted in diversified marketing activities. That is, the marketing activities were devised to meet the expectations of customers in the market where suppliers traditionally had greater bargaining power (Kim, 2005). Service stations commonly offer free car wash coupons, points mileage program, and price discount in order to stay competitive (Lee, Huh, Jeon, 2011). SK Energy came up with different service strategies focused on customer satisfaction management. As a result, the company remained number one in market share regardless of the difficulty industry faced in new customer acquisition.

\section{SK Energy's Customer Satisfaction Marketing Activities}

SK Energy values customer happiness management as its foremost in top priority and makes continuous effort for and customer-centered management. That is, it puts all its efforts to acquire new customers, promote them to loyal customers and continue to maintain high level of customer satisfaction.

The introduction of affinity credit cards with privileges including on spot discount is for a acquisition of new customers. Another way is to improve membership service with point mileage program and discount privileges for partnered companies. Next challenge faced is to retain the newly acquired customers and promote them to loyal customers. SK Energy has been actively involved in two-way communication to develop a point activation program taking advantage of Facebook, blog, mobile and EnClean.com. 'CS 119', 'ACE Program' and 'Employee CS Campaign' add onto improved customer satisfaction in the service stations. As discussed above, it is SK Energy's differentiated brand value serving as the key motivation to sustain its market leader position.

\subsection{SK Affinity Credit Card}

SK Energy partnered up with credit card companies offering credit and debit cards with 
exclusive privileges such as discount or point mileage program. "Yukong BC Card", issued in July 1993, was the first affinity credit card offered by oil refinery company. The card combined features of $\mathrm{BC}$ card with Yukong's unique benefits. Members were able to use the card not only at 240,000 stores affiliated to BC card but also at Yukong related franchises (Yonhap News, 1993). Customers' acceptance to 'Yukong BC Card' was high. The new marketing activity, in which, the company engaged in direct interaction with customers brought more enthusiasm than the traditional activities where customers were only treated with promotional gifts (Yonhap News, 1993). Ever since then, SK Energy has biggest number of partnerships with card companies. To the present year, with 47 different types of partnered credit cards, SK Energy obtained monthly average of 2 million customers with at least one affinity credit card. While SK Energy has different types of affinity credit cards, SK Energy allows customers to enjoy privileges with minimum prerequisites relative to its competitors. There are cards in which customers can enjoy 100KRW/liter discount or earn extra points by only spending $300,000 \mathrm{KRW}$ in the previous month. In fact, many of the privileges offered are often the best in the industry. BC Card's '365 days Save' is especially designed for frequent service station visitors: maximum of 300 points per liter is earned by filling up at any SK Service stations.

\subsubsection{On spot discount at service stations}

Customers often prefer to get extra discount than to earn extra points. The most preferred privileges that they would like to have in their credit card is 'gas fill up discount' (YTN, 2013). Many customers do take advantage of the privileges when they fill up. SK Energy's affinity credit cards have more privileges than average. SK Energy was first in the industry to issue card with on spot discount privileges (see 〈Table 2〉). For example, Hana SK’s ‘Club SK' offers on spot discount of 150KRW per liter (based on gasoline) at any SK Service stations. This is a unique partnership program only available at SK Energy. In the past, customers were only able to check the discounted price when their credit card bills were issued but not at the point of fill up. Unlike traditional discount program, SK Energy's affinity credit cards with on spot discount privileges allow customers to instantly check the discounted amount in their receipts (see 〈Figure 2〉) right after filling up. When the customer meets the prerequisite and becomes eligible to enjoy the privilege, SK Energy sends text messages (SMS) to each customer about the discounted price based on the listed gasoline price. The success of the program can be attributed to the principle that customers are more satisfied when they can actually see the actual benefit at the point of purchase. 
〈Figure 2〉 Receipt and SMS for on Spot Discount

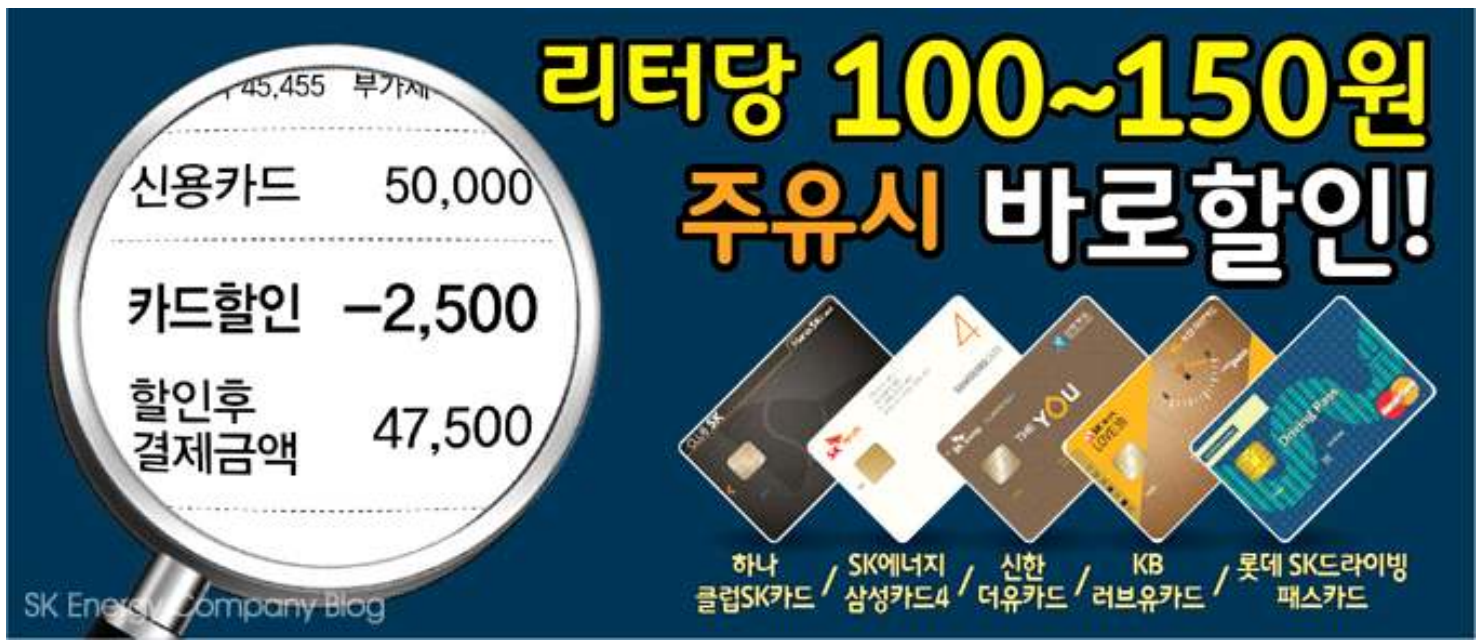

〈Table 2〉 Cards with on Spot Discount Privilege

\begin{tabular}{|l|}
\hline Hana SK 'Club SK' \\
\hline Hana SK 'Big Pot' \\
\hline Shinhan Card 'SK Energy THE YOUR' \\
\hline Lotte Card 'SK Driving Pass' \\
\hline Lotte Card 'SK-Lotte' \\
\hline Lotte Card 'SK Smart' \\
\hline Lotte Card 'SK Happy Auto' \\
\hline KB Card 'SK Love 油[you]' \\
\hline KB Card 'Love my children (T-Type)' \\
\hline Samsung Card 'Sk Energy Samsung Card 4' \\
\hline Hyundai Card 'Hyundai Card V' \\
\hline Hyundai Card 'SK Energy-Hyundai Card X' \\
\hline Woori Card 'Full Point' (1 April) \\
\hline Woori Card 'My Own Point' (1 April) \\
\hline Woori Card 'Earn them all' \\
\hline
\end{tabular}

\subsubsection{Performance of SK affinity credit} cards

The on spot discount, noted in the both receipt and text messages, also increased customer's perceived benefits on discount. Above all, it changed not only customers' awareness but also their attitude toward on gas discount. As a result, SK Energy earned the highest score in affinity credit card customer satisfaction (see $\langle$ Table 3〉) among four major oil refinery companies (SK Energy, GS Caltex, S-oil, Hyundai Oil Bank) in Korea.

〈Table 3〉 Affinity Credit Card Satisfaction Index by Service Station (score: 100)

\begin{tabular}{|c|c|c|c|}
\hline Service Station & 2012 Quarter 1 & 2013 Quarter 1 & $+/-$ \\
\hline SK & 64.9 & 71.7 & +6.8 \\
\hline GS & 67.9 & 71.0 & +3.1 \\
\hline S-Oil & 62.0 & 69.0 & +7.0 \\
\hline HD & 61.8 & 64.9 & +3.1 \\
\hline
\end{tabular}

*Source: 1,300 fill up customers, Gall up Korea 


\subsection{EnClean Bonus Card}

Enclean Bonus Card is a membership card for SK Service Station customers that offers point mileage program not only at the service station but also at partnered stores. It was first membership offered by an oil refinery company in 1996. The membership currently covers 17 million customers. Members can earn OK Cashbag points by filling up at any SK Service Stations. They can also cumulate or use OK Cashbag points ${ }^{2)}$ up to $20-30 \%$ of their spending at partnered shops. This attracts existing customers to re-visit SK Service Stations. In fact, the privileges that EnClean Bonus Card offered in 2012 recorded 1.58 million unit discounts equal to 2.7 billion $\mathrm{KRW}$.

\subsection{Two-way Communication}

SK Energy actively transforms itself from stereotypical image of oil refinery industry and tries to engage in communication with the public. Online-based communication channels are adopted as a response to change in popular media. SK Energy implements differentiated communication strategies by making use of EnClean.com (http: //www.enclean.com), blog and SNS (Facebook).

\subsubsection{EnClean.com}

EnClean.com is website for SK Service Station members where they can look up available benefits through 'EnClean Affiliated Privilege' and get recommendation for an affinity credit

$\langle$ Table 4〉 EnClean Affiliated Stores and respective privileges

\begin{tabular}{|c|l|}
\hline TOUS les JOURS & $20 \%$ discount, $5 \%$ extra points \\
\hline OUTBACK STAKEHOUSE & $20 \%$ discount, $10 \%$ extra points \\
\hline VIPS & $20 \%$ discount, $10 \%$ extra points \\
\hline China Factory & $20 \%$ discount, 10\% extra points \\
\hline Lotte Cinema & $5,000 \mathrm{KRW}$ discount on Fridays \\
& $3,000 \mathrm{KRW}$ all time discount or $5 \%$ extra points \\
\hline Yes24 & $5 \%$ discount, $3 \%$ extra points \\
\hline MERRELL & $15 \%$ discount, $7 \%$ extra points \\
\hline k-Swiss & $20 \%$ discounts, $10 \%$ extra points \\
\hline MINISTOP & $15 \%$ discounts, $1 \%$ extra points \\
\hline Mr. Pizza & $30 \%$ discounts or $15 \%$ extra points \\
\hline Speed Rent Car & Maximum discount of $40 \%$ (land), $75 \%$ (Jeju Island) \\
\hline Kyobo Bookstore & $1 \%$ extra points \\
\hline
\end{tabular}

*August 2013

2) OK Cashbag points can be earned by filling up at one of SK Energy's service stations with 'EnClean Bonus Card' or any affinitycredit card with OK Cashbag logo. 
card based on their fill-up habits. Members can also view their fill-up patterns and manage earned points at one-click.

There are many other privileges including 'Movie Plus', where members can watch movie at CGV/Primus Cinema at anytime and 'Themed Trip', where members are invited to a monthly trip with special theme. VIP members are provided with exclusive opportunities like 'VIP Premier' and 'VIP Premium Test-Drive', in which all can be enjoyed with their family and friends. To the present year, daily quiz event is carried out to privilege and entertain the members. Currently, there are 8.45 million members and the website records 2.05 million visits each year. In addition, 'Mobile EnClean' service is provided so that the customers can get updates on privileges of EnClean.com real-time (EnClean.com). Since 2013, microsite "Share love, share books" was constructed to make social contribution and deliver corporate social responsibility. Each gas fill up at SK Service Station will donate 5KRW to 〈Community Chest of Korea〉. Raised fund is used to build a small library for underprivileged community center children and encourage children to dream big.

\subsubsection{Blog}

Blog (blog.skenergy.com) (see 〈Figure 3〉) opened to provide information about refinery industry from oil formation to consumption and to promote two-way communication. While blog serves as a major medium of communication with information about products, business and technology, it also comments on public issues related to the company.

For example, 'Journey of Petroleum' is a webbased cartoon featuring general information about petroleum from oil development to its consumption, 'Infographic' contains industry information at glance, 'Kiss Virus' is a viral video theme based on 'Happy Energy'. Furthermore, articles write about the activities that SK Ulsan Complex does in plain language: single buoy mooring (SBM), shipping facilities and pro-

〈Table 5〉 EnClean Bonus card satisfaction index by service station (score: 100)

\begin{tabular}{|c|c|c|c|}
\hline Service Station & 2012 Quarter 1 & 2013 Quarter 1 & $+/-$ \\
\hline SK & 65.4 & 69.3 & +3.9 \\
\hline GS & 64.4 & 65.8 & +1.4 \\
\hline S-Oil & 61.2 & 65.2 & +4.0 \\
\hline HD & 54.3 & 60.2 & +5.9 \\
\hline
\end{tabular}

* Source: 1,300 fill up customers, Gall up Korea

3) A Single buoy mooring (SBM) (also known as single-point mooring or SPM) is a loading buoy anchored offshore, that serves as a mooring point and interconnect for tankers loading or offloading gas or liquid products (Wikipedia, 2014). 


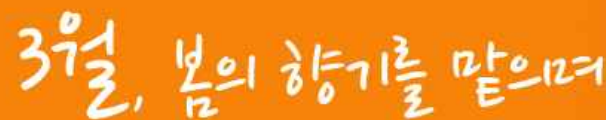
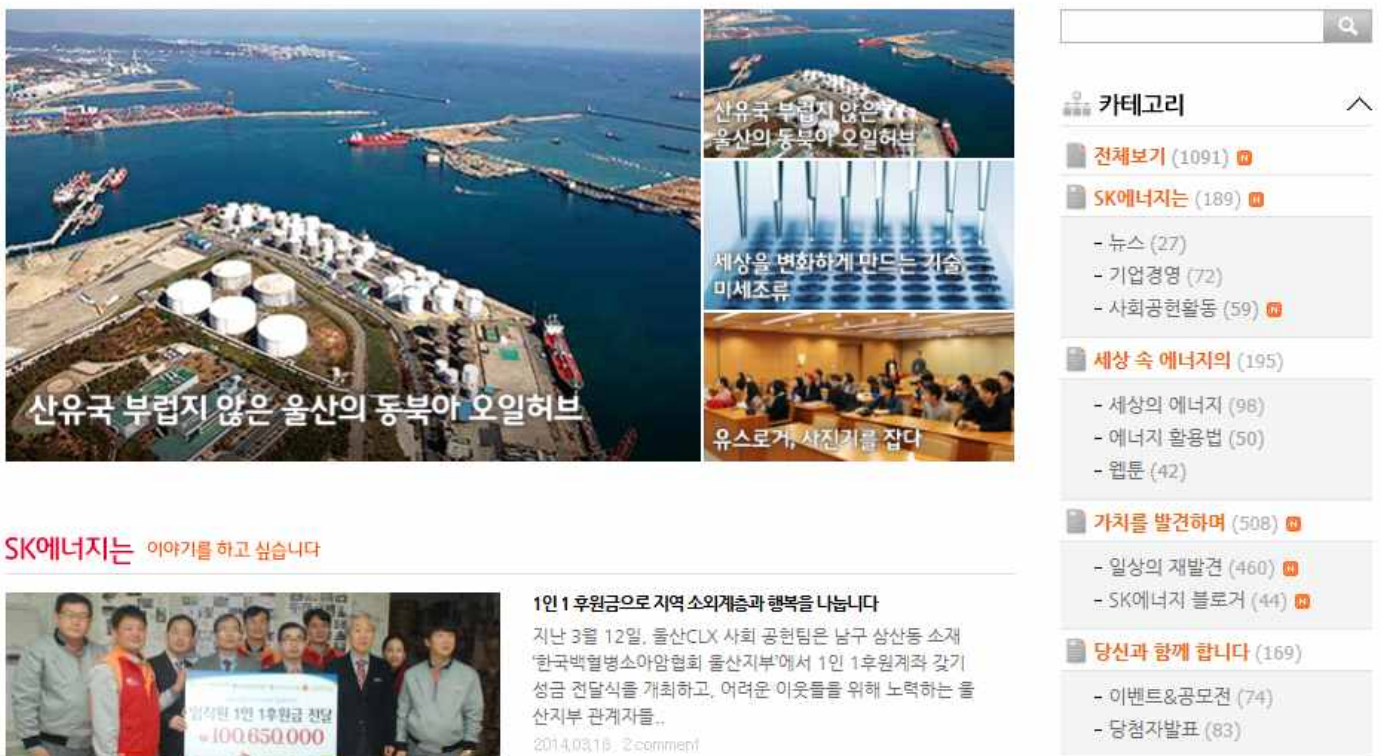

SK에너지는 이야기를 하고 싶습니다

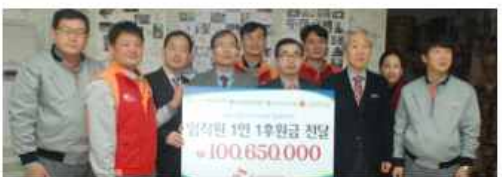

1 인 1 후원금으로 지역소외계층과 행복을 나납니다

지난 3 월 12 일, 물산 CLX 사회 공현팀은 남구 삼산동 소재 한국백혈병소아암협회 울산지부에서 1 인 1 후원계좌 갖기 성금 전달식를개최하고. 어려운 이웃들를 위해 노력하는 들 산지부 관계자들. duction process. It also provided fruitful information to the public. One of the articles featured the history of the company at its $50^{\text {th }}$ anniversary reviewing its performance from Korea Petroleum Association to present (Ulsan Maeil, 2013). Student reporters called 'Youthlogger' and employee reporters called 'Energylogger' also participate and provide 1:1 mentoring. The contents are in-depth but the creative layout and style reflect the characteristics of student reporters. Blog's layout was designed to improve fluency and to encourage customer interaction (E-Times News, 2012). The fact that blog goes beyond mere introduction of the company and provides useful information received good response for the customers.

\subsection{K Exclusive Privilege Program}

SK Energy delivers values in customer's life with '3K (3,000 points) Exclusive Privilege' program. This program was launched in April 2012 (see 〈Figure 4〉). Once the customer reaches 3,000 points, the customer can redeem 9,000KRW worth gifts that were popular at that time which were 5 packs of Ggo-ggo Myun and 5 packs of Namja ramen in phase 1 of the program. Through this unique marketing activ- 
〈Figure 4〉 '3K Exclusive Privilege Program' Flyers

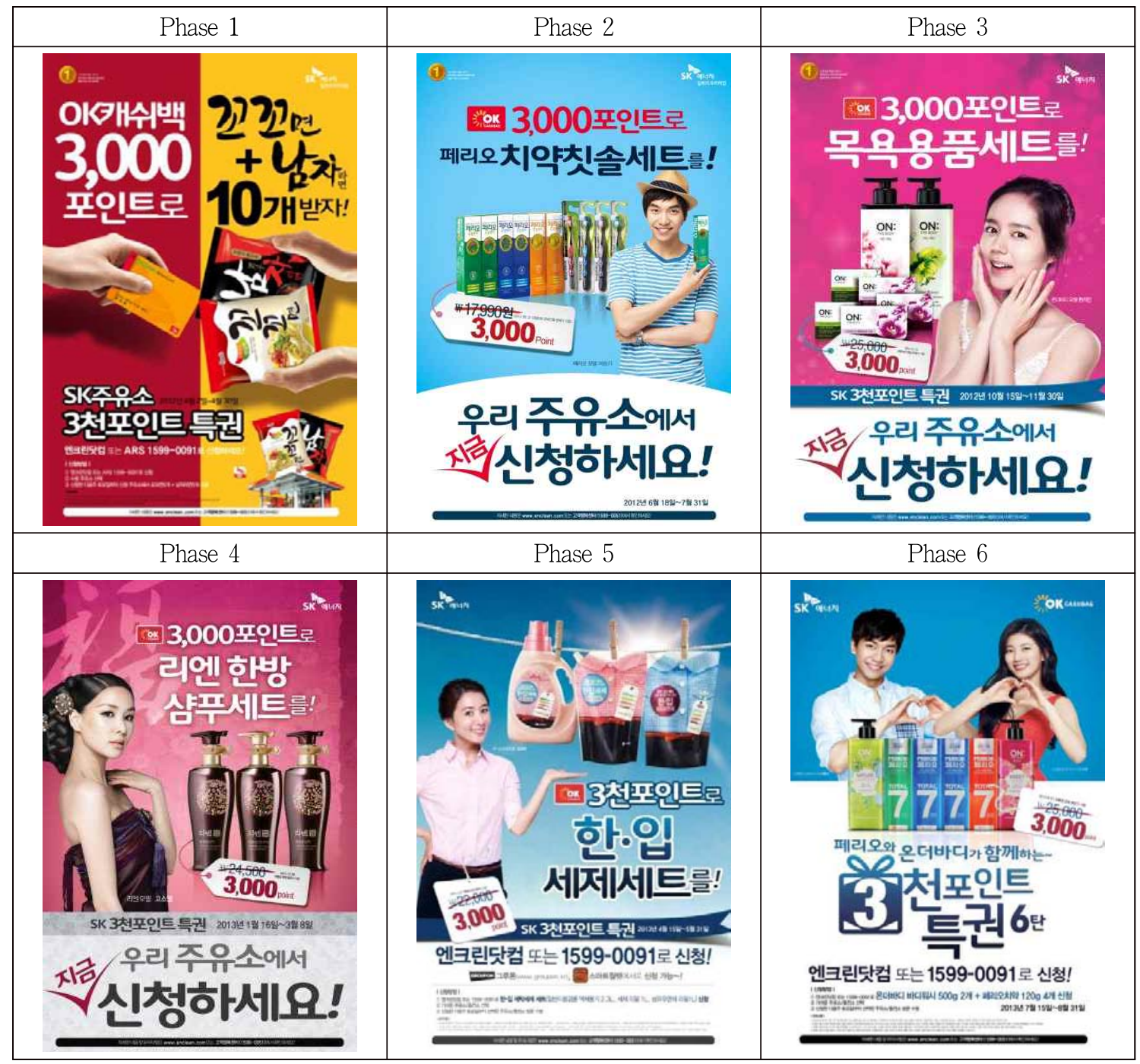

ity, the customers were able to enjoy more benefits than the face value of the points by using OK Cashbag points. SK Service Station network served as distribution channel to provide customers with gifts that are supplied by manufacturers at low price sourcing.

206 ASIA MARKETING JOURNAL Vol. 16 No.01 April 2014

\subsection{1 '3K Exclusive Privilege' registration procedure}

Any member who accumulated more than 3,000 points of OK Cashbag points are eligible to join the privilege program via EnClean.com (http://www.enclean.com) or hotline (1599-0091). 
The customer can choose a SK Service Station (some stations are not applicable) for gift pick-up and 3,000 points will be automatically deducted upon successful application. The pickup is available onward from Saturday after the week of application and customer can visit the service station they chose with OK Cashbag card for redemption.

\subsubsection{Characteristics of 3K Exclusive Privilege}

'3K Exclusive Privilege' program led positive outcome to SK Energy, customers and merchants (see $\langle$ Figure 5〉). First of all, the program makes point value-up possible, an unconventional privilege in the industry. When customers use OK Cashbag through '3K Exclusive Privilege' program, they can enjoy more priv- ileges than what they could have done with face value of the points. Currently SK Energy provides approximately 3 8 times higher valued gifts (see 〈Table 6〉). Accordingly, customers get the opportunity to buy daily necessities at cheaper price: ramen set (Phase 1), toothbrush and toothpaste set (Phase 2), body wash duo (Phase 3), oriental shampoo (Phase 4). From the point of merchants, they have the opportunity to increase their brand awareness and advertise their products by supplying the goods in bulk to SK Energy. This is evaluated as win-win strategy for both merchant and SK Energy. Lastly, SK Energy can transform the new customers gained by SK Service Station membership program into loyal customers. '3K Exclusive Privilege' will eventually lead revisits and the brand value of SK Service Station will consequently increase.

\section{〈Figure 5〉 3K Exclusive Privilege Program Outline}

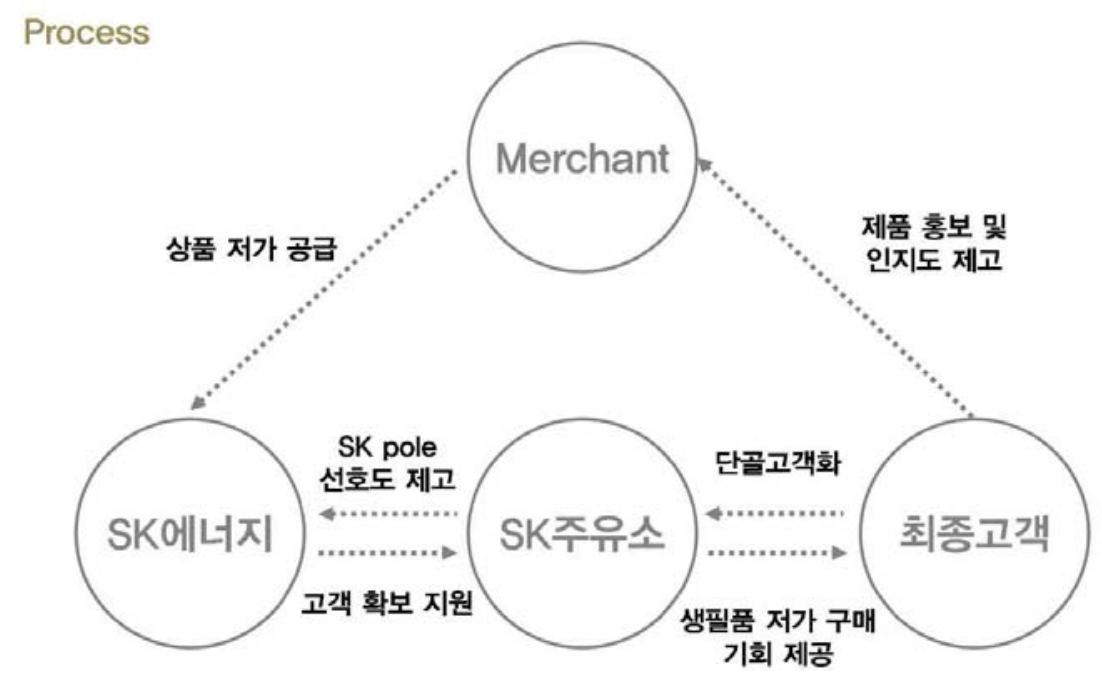

SK Energy's Customer Satisfaction 207 
〈Table 6〉 2012-2013 Privileges

\begin{tabular}{|c|c|c|c|c|c|}
\hline \multirow{2}{*}{} & \multicolumn{3}{|c|}{2012} & \multicolumn{2}{c|}{2013} \\
\cline { 2 - 6 } & Phase 1 & Phase 2 & Phase 2 & Phase 4 & Phase 5 \\
\hline \multirow{2}{*}{$\begin{array}{c}\text { Gift } \\
\text { KRW })\end{array}$} & $\begin{array}{c}\text { Instant } \\
\text { Noodle Set } \\
(10 \mathrm{~K})\end{array}$ & $\begin{array}{c}\text { Toothbrush \& } \\
\text { toothpaste } \\
(18 \mathrm{~K})\end{array}$ & $\begin{array}{c}\text { Body wash } \\
\text { set } \\
(25 \mathrm{~K})\end{array}$ & $\begin{array}{c}\text { Oriental } \\
\text { Shampoo } \\
(25 \mathrm{~K})\end{array}$ & $\begin{array}{c}\text { Detergent set } \\
(22 \mathrm{~K})\end{array}$ \\
\hline $\begin{array}{c}\text { Value } \\
(\text { KRW })\end{array}$ & 2 billion & 6.1 billion & 11 billion & 10.3 billion & 8.1 billion \\
\cline { 2 - 6 } & \multicolumn{3}{|c|}{ Total 19.1 billion } & \multicolumn{2}{c|}{ Total 18.4 billion } \\
\hline
\end{tabular}

\subsubsection{Performance}

In 2012, '3K Exclusive Privilege' program became leading event held by SK Energy with approximately 1 million participants in one year. This practical event maximized customers' satisfaction and fulfilled their needs at contact place, SK Service Station. Within only one year, in 2012, 1 million customers joined the event in three different phases (see〈Table 7〉).

Service station, the distribution channel for the event, also reported high satisfaction (see $\langle$ Table 8〉). The satisfaction score increased for two events held in 2013's than those three events held in 2012. Service stations were able to see increase in sales and showed improvement in customer management.

The participants have been showing high satisfaction (see 〈Table 9〉). After termination of 2013's last event, SK Energy surveyed 500 customers and all replied that they are willing to participate the next '3K Exclusive Privilege'

〈Table 7〉 2012-2013 Participants

\begin{tabular}{|c|c|c|c|c|c|}
\hline \multirow{2}{*}{} & \multicolumn{3}{|c|}{2012} & \multicolumn{2}{c|}{2013} \\
\cline { 2 - 6 } & Phase 1 & Phase 2 & Phase 3 & Phase 4 & Phase 5 \\
\hline Gift & $\begin{array}{c}\text { Instant Noodle } \\
\text { Set } \\
(10 \mathrm{~K})\end{array}$ & $\begin{array}{c}\text { Toothbrush \& } \\
\text { toothpaste } \\
(18 \mathrm{~K})\end{array}$ & $\begin{array}{c}\text { Body } \\
\text { wash set } \\
(25 \mathrm{~K})\end{array}$ & $\begin{array}{c}\text { Oriental } \\
\text { Shampoo } \\
(25 \mathrm{~K})\end{array}$ & $\begin{array}{c}\text { Detergent set } \\
\text { (22K) }\end{array}$ \\
\hline No. of Participants & 100,000 & 340,000 & 440,000 & 410,000 & 370,000 \\
\hline
\end{tabular}

〈Table 8〉 Distribution Channel Satisfaction Index (536 service stations)

\begin{tabular}{|c|c|c|c|}
\hline Score (out of 5) & Satisfaction Level & $\begin{array}{c}\text { Effective customer } \\
\text { management }\end{array}$ & Increase in sales \\
\hline Phase 5 & 4.4 & $83 \%$ & $58 \%$ \\
\hline Phase 4 & 4.2 & $77 \%$ & $49 \%$ \\
\hline Phase 1-3 & 3.8 & $75 \%$ & $43 \%$ \\
\hline
\end{tabular}

\footnotetext{
*Source: SK Energy
} 
〈Table 9〉 Participants $(n=500)$ Satisfaction Index

\begin{tabular}{|c|c|}
\hline Customer Satisfaction & 4.3 \\
\hline Perceive higher value in Cashbag point & $98 \%$ \\
\hline Improved brand image and influence on choosing service station & $97 \%$ \\
\hline Participation in next '3K Exclusive Privilege' Program & $100 \%$ \\
\hline
\end{tabular}

*Source: SK Energy (June 2013)

program. The event improved customers' perceived benefits on OK Cashbag points, influenced customers' choice of service station and finally enhanced the entire brand image. This proves how the differentiated marketing activity can bring in higher customer satisfaction.

\subsection{Field CS Improvement}

\subsubsection{Team CS 119}

SK Energy has been making efforts to improve and reinforce customer satisfaction in the field, service station. One example is team 'CS 119', a consulting program, focused on reinforcing customer service in the field rotated across all SK Service Stations.

The program was first implemented in 2011. CS expert visits the service station and diagnoses current level of customer service in order to improve field-based CS execution rate. Different methods and approaches are used to diagnose the CS level and recommendations are given based on these results. When solutions are devised according to recommendations, the same expert will provide customized training and coaching leading significant change in the cus- tomer service. After executing the suggested solutions for a month, CS expert will re-visit the service station and give feedback on the progress. If any flaw is found, CS expert will closely stay in contact with the service station and give directions for improvements and support full implementation of CS program. This CS consulting allows all SK Service Stations to have standardized CS and build image of a service station where customers would like to visit again. In particular, team 'CS 119' gives high priority to the service stations with lowest CS level. In 2012, 9 teams of 'CS 119' visited 2,400 service stations and pulled up customer satisfaction with better service.

\subsubsection{CS Codes of conduct for service stations}

SK Energy developed its own 'SK Service Station CS Codes of Conduct' in order to deliver standardized CS service to the customers at all of its stations. 'SK Service Station CS Codes of Conduct' lists out must-do items for all stations. The items in the list have to be easy to execute in the field and should include the core values that are perceived to be highly im- 
portant to the customers. That is, items that influence customer satisfaction the most.

The items in 'SK Service Station CS Codes of Conduct' were recommended by the service stations, the distribution channel, and by customers from the survey. Based on the premise that the store will be kept clean and hygienic, three major items were developed: 'Greetings', 'Fast response', and 'Instructions to affinity and membership card'. 'SK Service Station CS
Codes of Conduct' is both easy to understand and execute at the stations.

SK Energy also introduced 'Service Execution Action Plan' helping its service station staffs acquire skills listed in the codes of conduct. Cartoon posters (see 〈Figure 6〉) illustrating the contents of 'SK Service Station CS Codes of Conduct' were distributed to the service stations and were posted on e-Market ${ }^{4)}$ at the same time. During the CS 119 consulting, staffs were

〈Figure 6〉Instructions for CS Codes of Conduct

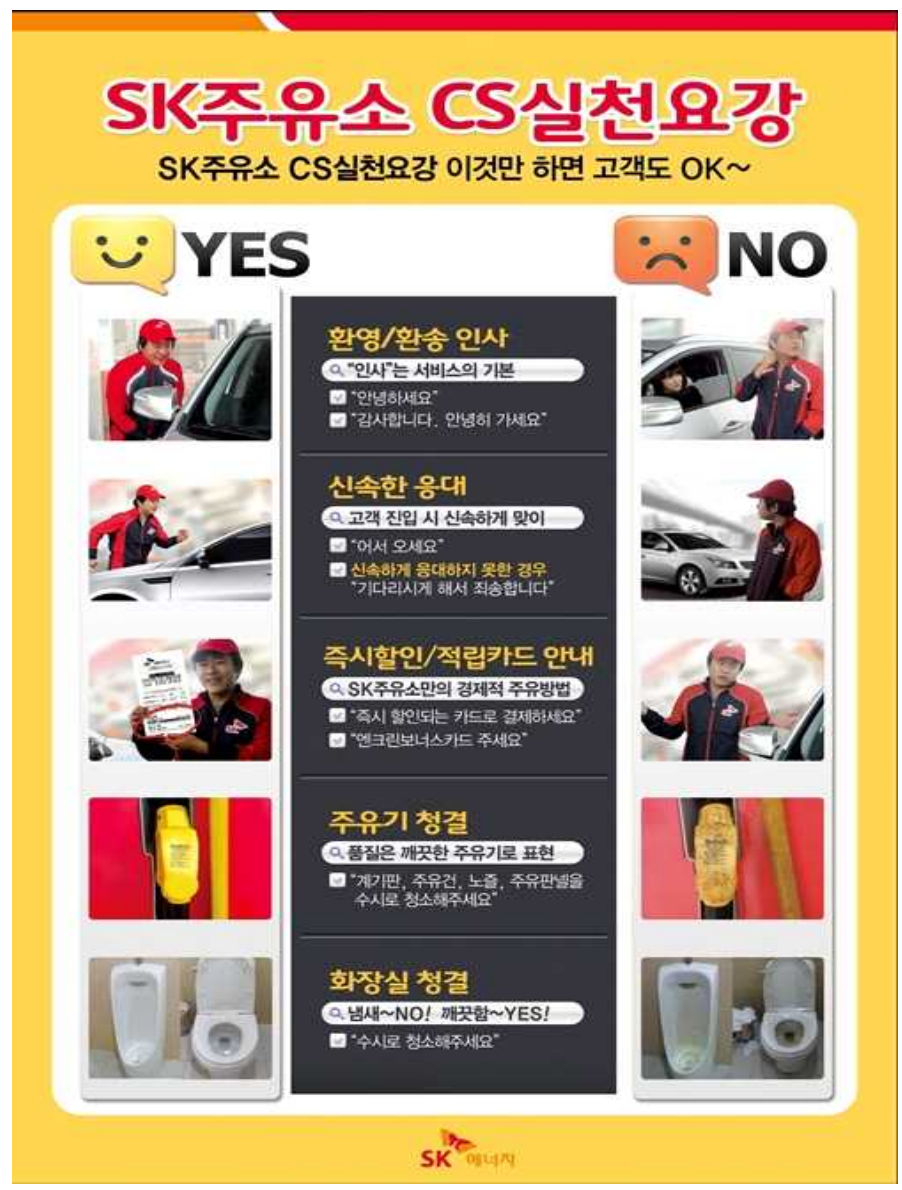

4) Intranet for service stations 
always reminded about the codes of conduct for future improvements. In order to encourage active participation of service stations, SK Energy held an event for the service stations. 780 stations participated from April 2012 to September 2012 in 'CS Codes of Conduct Photo Contest'. The event called for photos that demonstrated listed codes of conduct (see 〈Figure 7〉). 50 stations were chosen based on the votes and upload time and were awarded free pizza meals; one station earned 500,000KRW subsidy for staff social gathering.

\subsubsection{ACE (Appearance Cleanliness Evaluation)}

ACE refers to SK Energy's service station evaluation system executed since 1998. It is a system that monitors CS on the field at service stations. The system allows regular evaluation of SK Service Station's customer satisfaction. After the evaluation, feedback is given to sales department and to the service station to generate potential solutions. The solutions are quickly promoted and enable steady growth in customer satisfaction level.

ACE assesses the customer satisfaction level by visiting 2,100 SK Service Stations (both direct, and self managed stations) in mystery shopping method. The items taken into consideration include general satisfaction, service employee satisfaction, cleanliness of the station and other facilities and concerns for customer convenience. Each evaluation is repeated three times per year. The results are reported directly to the respective service station and posted online.

\subsubsection{Employee CS Campaign}

In May 2012, 1,800 SK Energy employees including SK Energy’s President Park Bong-Gyun and transportation engineers participated in 'SK Service Station Hygiene and Care Campaig'. The participation improved the hygiene of the service stations and enhanced the idea of CS (see 〈Picture 5〉). During the program, SK Energy employees personally clean up the lu-

〈Figure 7〉 Example of CS Codes of Conduct Practice
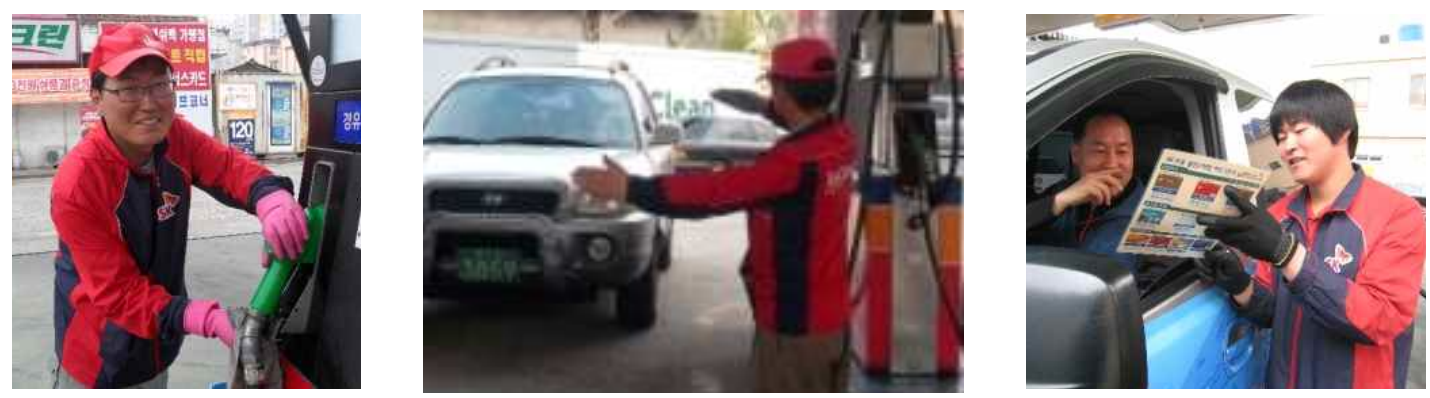

SK Energy's Customer Satisfaction 211 

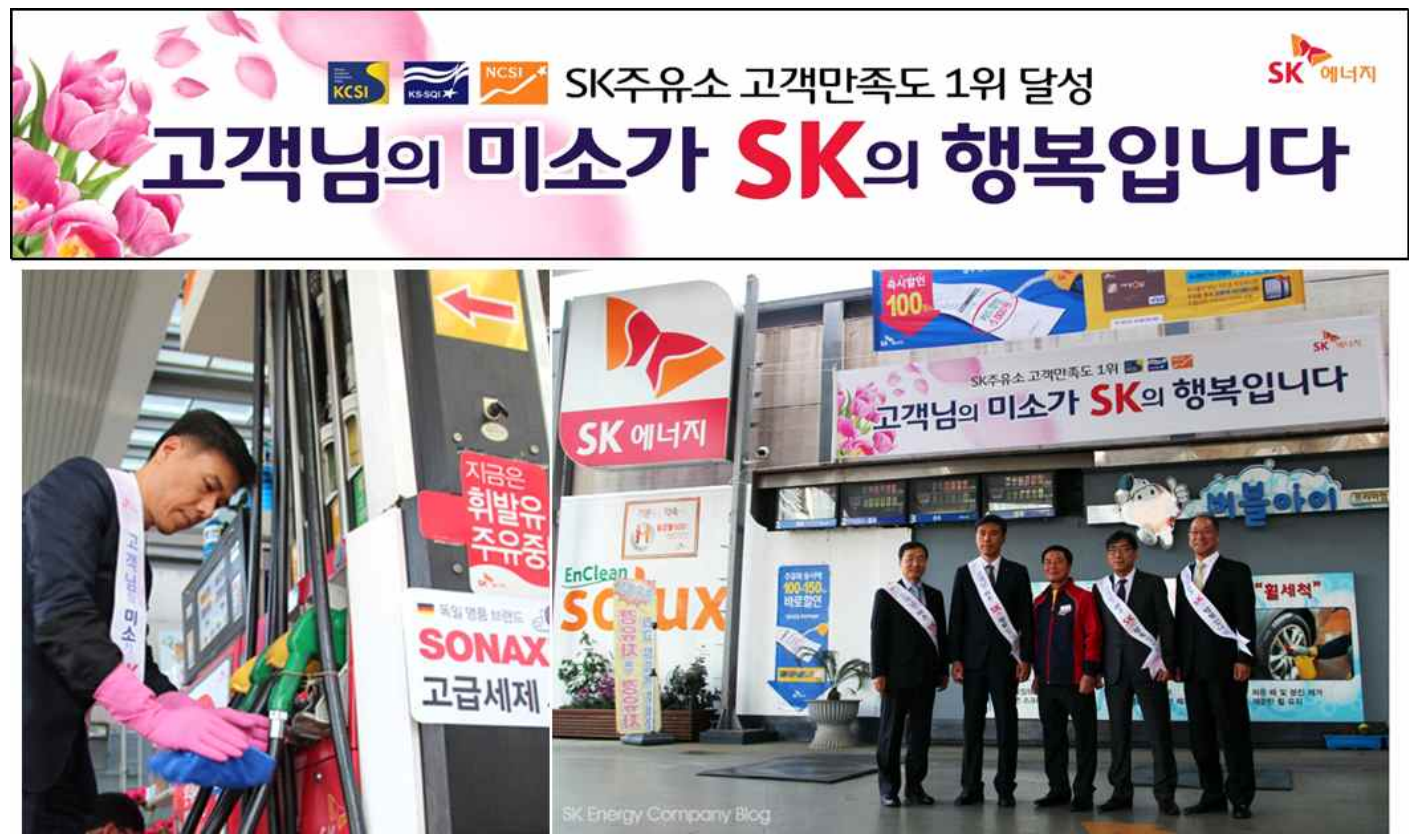

bricator and pick up the waste around the station. The activity incorporates the company's value that will always greet customers in a clean setting. Flyers with information about on spot discount card, '3K Exclusive Privilege' program are also handed out to promote such marketing activities (SK Energy blog). SK Energy employees' CS campaign highly contributed to improvement on customer satisfaction.

\section{Result}

\subsection{Overall Performance}

SK Energy won $1^{\text {st }}$ place among service sta- tions for NCSI (National Customer Satisfaction Index) in December $18^{\text {th }} 2012$, followed by winning KCSI (Korea Customer Satisfaction Index) in September and KS-SQI (Korean StandardService Quality Index) in October. That is, to be awarded first in all three major customer satisfaction index (SK Energy blog). The customer satisfaction index evaluates customer's perceived satisfaction, reliability, values, quality, and repurchase rate. The evaluated items suggest that SK Energy is going beyond the industry average for more care, better hygiene, greater benefit and superior customer impression. This is the result of concentrating on marketing activities that create customer value through discovering the right customer needs and build a 'happy' service station. 


\subsection{Future Plans}

SK Energy already positioned itself as 'No.1 Brand' in service station industry with its prioritization in customer satisfaction strategy. The customer-centered management will remain to maximize customer satisfaction as a response to customers' choice for 'No.1 Brand'. First, SK Energy aims at expanding its partner channels to differentiate its affinity credit cards from its competitors and provide the best loyalty program to its members. In fact, SK Energy has been making efforts to acquire new customers by maximizing the advantages those affinity credit cards and membership cards offer. Second, it plans to leverage more on ' $3 \mathrm{~K}$ Exclusive Privilege' program that has been receiving most attention from the members. '3K Exclusive Privilege' program, the leading marketing activity of SK Energy, looks for active communication with customers and is aimed at transforming them into loyal customers. In order to reach its goal, highly tailed strategy like personalized gifts is required to maximize customer satisfaction. Lastly, in long-term, SK Energy started exploring new approaches to enhance unique features of its CS Program. The balance between planning and execution should be emphasized. Unlike few decades ago, many service stations have developed different programs for customer satisfaction. Therefore, SK Energy should also upgrade its CS Program and try its best to differentiate itself from its competitors. One way to this approach would be focusing on increasing the execution rate at the service stations.

\section{References}

Fornell, Clases (1992), “A National Customer Satisfaction Barometer: The Swedish Experience," Journal of Marketing, 55(January), 1-21.

Han S.H. (2012), '[We lead the internet communication] $\langle 2\rangle$ SK Energy', E-Times News, 17th December 2012

Jang H.J. (2013), “SK Energy-GS Caltex, first in the industry, who will take the market lead for new business opportunity?," EToday, 4th February 2013

Kim, H.S. (2012), "Era of Self-serviced Service Stations Begins," Seoul Economic Daily, 19th October 2012

Korea Oil Station Association, October 2012

Korea Oil Station Association http://www. ikosa.or.kr

Korea Petroleum Association (1995), “Abolition of Zoning Restrictions," KA, 27th December 1995

Lee, Y.O. (2013), "SK Energy, transforms the image of oil refinery industry," Ulsan Maeil Daily, 1st April 2013

Noh, W.M. (212), "Intensified competition among service stations... increase in close down 
rate..." Maeil Economic Daily, 30th November 2012

Yonhap News (1993), "BC Card partners up with Yukong," Yonhap News, 10 July 1993 Yonhap News (1996), "Yukong membership hits 2 million," Yonhap News, 6th November 1996
SK Energy http://www.skenergy.com

Wikipedia http://en.wikipedia.org/wiki/Single _Buoy_Mooring

YTN(2013), YTN News, 7th March 2013 